http://dx.doi.org/10.12775/szhf.2017.021

Karol Michalski

Uniwersytet Śląski, Katowice, Polska

K.MICHALSKI@AON.AT

\title{
Heidegger, Luter i problem grzechu
}

\section{Pochodzenie teologiczne}

W znanej wypowiedzi Martin Heidegger wskazuje na ważność teologicznych korzeni dla rozwoju swojego myślenia. „Bez tego teologicznego pochodzenia nigdy bym nie wszedł na drogę myślenia. Lecz pochodzenie pozostaje zawsze przyszłością." To pochodzenie jest pochodzeniem ze świata Polnej drogi (Feldweg). Polna droga, wielka metafora życia, prowadzi w otwartość i - inaczej niż Leśne przecinki (Holzwege) - znowu z powrotem do domu, aż do murów miasta Meßkirch, nad którymi wznosi się wieża kościoła św. Marcina (Martinskirche). Heidegger mówi: „Lecz przyzwanie polnej drogi mówi tylko tak długo, dopóki są ludzie, którzy urodzeni w jego powietrzu, potrafią go słuchać. Oni są posłusznymi sługami swojego pochodzenia, ale nie parobkami machinacji”' ${ }^{2}$. Heidegger powołuje się w cytacie o przyszłości na pochodzenie $\mathrm{z}$ miasta Meßkirch, na swoje początki jako studenta teolo-

${ }^{1}$ M. Heidegger, Unterwegs zur Sprache, Band 12, Gesamtausgabe, Hrsg. Fr. W. von Herrmann, Vittorio Klostermann, Frankfurt am Main 1985, s. 96. Tłumaczenia wszystkich cytatów są mojego autorstwa.

${ }^{2}$ M. Heidegger, Der Feldweg, [w:] tenże, Aus der Erfahrung des Denkens, Band 13, Gesamtausgabe, Durchgesehener Text der Einzelveröffentlichungen und Einzelausgaben, auf- 
gii katolickiej, a tym samym na pochodzenie religijne, które pozostanie dla niego w pewien sposób ciągle przyszłością. W przemówieniu z okazji 700-lecia miasta Meßkirch w lipcu 1961 roku pisze: „Dzisiaj ma swe pochodzenie w tym, co było, a jednocześnie wystawione jest na to, co nadchodzi"3.

Na początku lat dwudziestych ubiegłego stulecia Heidegger podkreśla odniesienie swojego myślenia do pochodzenia teologicznego i religijnego. W liście do swojego ucznia Karla Löwitha, w którym nazywa się „chrześcijańskim teologiem”, pisze: „Pracuję konkretnie faktycznie z mojego ,ja jestem’ - z mojego w ogóle duchowego faktycznego pochodzenia - milieu - powiązań życiowych, z tego, co mi jest stąd dostępne jako żywotne doświadczenie,

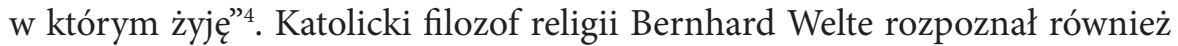
znaczenie rodzinnych stron dla swojego ziomka: „Heidegger był mocno przywiązany do tego, co rodzime w ojczyźnie i odkrył to dla siebie w małym miasteczku Meßkirch, i w rozległym przestrzennie krajobrazie, który do niego przynależy, i w dziwnych i tajemniczych ludziach, którzy tam żyją" Jak dalece teologiczne i religijne pochodzenie Heideggera pozostanie dla jego drogi filozoficznej przyszłością, pokazuje się w wypowiedzi Edmunda Husserla, który w 1919 roku określił go jako „rzeczywiście religijnie nastawioną osobowość"'. Hans-Georg Gadamer określa tekst Heideggera Phänomenologische Interpretationen zu Aristoteles z 1922 roku, zwany też Natorp-Bericht ${ }^{7}$,

grund von Verbesserungen des Autors in den Handexemplaren gelegentlich geringfügig geändert, Hrsg. H. Heidegger, Vittorio Klostermann, Frankfurt am Main 2002, s. 89.

${ }^{3}$ M. Heidegger, 700 Jahre Meßkirch (Ansprache zum Heimatabend am 22. Juli 1961), [w:] tenże, Reden und andere Zeugnisse eines Lebensweges, Band 16, Hrsg. H. Heidegger, Vittorio Klostermann, Frankfurt am Main 2000, s. 575.

${ }^{4}$ Brief Martin Heidegger an Karl Löwith vom 19. August 1921, [w:] Dietrich Papenfuss, Otto Pöggeler (Hrsg.), Zur philosophischen Aktivität, Bd. 2: Im Gespräch der Zeit, Frankfurt am Main 1990, s. 29. Karl Löwith, uczeń Heideggera żydowskiego pochodzenia, opowiadał, że w gabinecie Heideggera w Marburgu wisiał ekspresywny obraz ukrzyżowanego Jezusa. A sam otrzymał kiedyś od niego O naśladowaniu Chrystusa Tomasza a Kempis.

${ }^{5}$ B. Welte, Erinnerungen an ein spätes Gespräch, [w:] Martin Heidegger, Bernhard Welte, Briefe und Begegnungen, Klett - Cotta Verlag, Stuttgart 2003, s. 148.

${ }^{6}$ Brief Edmund Husserl an Rudolf Otto vom 5. März 1919, [w:] H.-W. Schütte, Religion und Christentum in der Theologie Rudolf Ottos, Berlin 1969, s. 139.

${ }^{7}$ M. Heidegger, Phänomenologische Interpretationen zu Aristoteles (Anzeige der hermeneutischen Situation), Ausarbeitung für die Marburger und die Göttinger Philosophische Fakultät, (Herbst 1922), [w:] tenże, Phänomenologische Interpretationen ausgewählter Abhandlungen des Aristoteles zur Ontologie und Logik, Band 62, Gesamtausgabe, Hrsg. G. Neumann, Vittorio Klostermann, Frankfurt am Main 2005. 
jako Heideggers "theologische” Jugendschrift". Pisze Gadamer "Znaczenie tego manuskryptu (Natorp-Bericht) leży dzisiaj dla nas w tym, że Heidegger wówczas był jeszcze w trakcie poszukiwania. Czego szukał Heidegger, to była odpowiednia interpretacja i antropologiczne rozumienie świadomości chrześcijańskiej. W końcu był on, tak jak my wszyscy, dzieckiem oświecenia i epoki nauki, i miał problemy z chrześcijańskim przekazem nauki kościołów. Tak więc zadaniem Heideggera, który doświadczył godnego uwagi przeszkolenia (Schulung) na wysokim naukowym niveau, szczególnie w historii kościoła i dogmatów, było radykalne uwolnienie się od piętna chrześcijańskiej dogmatyki”" Heidegger podjął się tego zadania, dokonując w wykładach Einleitung in die Phänomenologie der Religion ${ }^{10} \mathrm{z}$ roku 1920/21 i Augustinus und der Neuplatonismus ${ }^{11} \mathrm{z} 1921$ roku, interpretacji fragmentów z pierwszego i drugiego listu Apostoła Pawła do Tesaloniczan, Pawłowego listu do Galatów i teologii augustyńskiej. Zadania interpretacji chrześcijańskiej świadomości podjął się także w niewygłoszonym wykładzie z 1919/20 Die philosophischen Grundlagen der mittelalterlichen Mystik ${ }^{12}$.

\section{Teologia Lutra}

Martin Heidegger, syn kościelnego z Meßkirch, był od wczesnych lat konfrontowany ze sporami międzywyznaniowymi. Kiedy starokatolicy w Meßkirch urośli w siłę i stali się większością, został im przyznany centralny katolicki kościół św. Marcina. Katolicy musieli szukać miejsca do spotkań religijnych w innym kościele. Jakiś czas potem znowu katolicy stanowili więk-

${ }^{8}$ M. Heidegger, Phänomenologische Interpretationen zu Aristoteles (Anzeige der hermeneutischen Situation) mit einem Essay von Hans-Georg Gadamer, Rote Reihe, Vittorio Klostermann, Frankfurt am Main 2013.

${ }^{9}$ H.-G. Gadamer, Heidegger ,theologische” Jugendschrift, [w:] M. Heidegger, Phänomenologische Interpretationen zu Aristoteles, Rote Reihe, Vittorio Klostermann, Frankfurt am Main 2013, s. 67.

${ }^{10}$ M. Heidegger, Einleitung in die Phänomenologie der Religion, [w:] tenże, Phänomenologie des religiösen Lebens, Band 60, Gesamtausgabe, Hrsg. M. Jung, T. Regehly, C. Strube, Vittorio Klostermann, Frankfurt am Main 1996.

${ }^{11}$ M. Heidegger, Augustinus und der Neuplatonismus, w: tenże, Phänomenologie des religiösen Lebens, Band 60.

${ }^{12}$ M. Heidegger, Die philosophischen Grundlagen der mittelalterlichen Mystik, [w:] tenże, Phänomenologie des religiösen Lebens, Band 60. 
szości i w 1895 roku kościół parafialny został im przywrócony. Jako student teologii Heidegger wypowiedział się w piśmie zrzeszenia katolickich studentów „Der Akademiker”. W tekście zajął pozycję prawicowego skrzydła katolików, odrzucającego modernizm, potępiony przez papieża. Kiedy w 1915 roku sformułował curriculum vitae dla przewodu habilitacyjnego, ujął jasno swoje dążenia filozoficzne. Chociaż znana była mu nowsza filozofia, począwszy od Kanta, to jednak jego „filozoficzne podstawowe przekonania pozostały przekonaniami filozofii arystotelesowsko-scholastycznej”"13.

Z pismami Lutra Heidegger spotkał się dosyć wcześnie, podczas studium teologii we Fryburgu. W latach 1959 i 1961 Otto Pöggeler, będąc w trakcie przygotowywania wprowadzenia do dzieła Heideggera, odwiedzał go we Fryburgu-Zähringen. Podczas jednego ze wspólnych spacerów po mieście Heidegger zatrzymał się nagle i wskazał na okno konwiktu teologicznego, mówiąc. „Za tym oknem siedziałem i czytałem Lutra”"14. Przez to chciał odrzucić podejrzenie, że poznał Lutra przez tak zwaną protestancką teologię dialektyczną (Barth, Gogarten) po pierwszej wojnie. W 1909 roku Heidegger przybył do konwiktu (seminarium duchowne) z zamiarem studiowania teologii katolickiej. Przebywając tam w latach 1909-1911, natknął się na wczesny wykład Lutra o liście do Rzymian. Wydanie Johannesa Fickersa Luthers Vorlesung über den Römerbrief 1515/16 ukazało się jako pierwszy tom serii pod tytułem Anfänge reformatorischer Bibelauslegung ${ }^{15}$. Wydawca ujął we wprowadzeniu wspomnienia postarzałego Reformatora dotyczące jego dawnego przełomu: „prośba z Psalmów In iustitia tua libera me poprowadziła wstrząśniętego i przenikniętego strachem augustiańskiego mnicha i egzegety do Pawła. „Wielkość” niemieckiej mistyki, przede wszystkim Taulera, była dla niego „Pociechą i pomocą w najcięższym czasie zwątpienia”. Sytuacja naukowa w Wittenberg, gdzie na pierwszym uniwersytecie bezwyznaniowym nauczał Luter, była ukształtowana przede wszystkim przez późną scholastykę, skotystów, Okhama i Biela. Dla poszukiwań Lutra istotne okazało się zmierzenie się z teologią Augustyna. Młody Heidegger mógł w drodze Lutra, jak w zwierciadle, widzieć swoją własną drogę.

Stary Luter krótko przed śmiercią wskazał na to, że list do Rzymian miał dla niego decydujące znaczenie. Jego życie było naznaczone strachem przed

\footnotetext{
${ }^{13}$ M. Heidegger, Reden und andere Zeugnisse eines Lebensweges, Band 16, dz. cyt., s. 38.

${ }^{14}$ O. Pöggeler, Heideggers Luther - Lektüre im Freiburger Theologiekonvikt, [w:] Heidegger und die Anfänge seines Denkens, Hrsg. A. Denker, H.-H. Gander, H. Zaborowski, Verlag Karl Alber, Freiburg-München 2004, s. 185.

${ }^{15}$ Luther, Vorlesung über den Römerbrief 1515/16, Hrsg. J. Ficker, Leipzig 1908.
} 
śmiercią i sądem ostatecznym. W trakcie teologicznych poszukiwań powoli jednak oddalił się od myślenia o sprawiedliwości Bożej w przyjętym wtedy znaczeniu, jako aktywnej, karzącej sprawiedliwości. Uczył się ujmować Bożą sprawiedliwość pasywnie od strony miłości, w której Bóg umożliwia człowiekowi poprzez wiarę stać się usprawiedliwionym, to znaczy zasługującym na zbawienie.

Jak mógł jednak Luter znaleźć się na biurku Heideggera w konwikcie teologicznym, w ówczesnym Fryburgu, gdzie mieszały się ze sobą południowo-zachodni niemiecki liberalizm, neokantyzm i ortodoksyjny katolicyzm? Heideggera lektura Lutra pojawia się w określonej sytuacji. Jednocześnie bliska jest mu w tym czasie mistyka średniowiecza, gdzie preferuje mistrza Eckharta przed Taulerem. Luter miał jednak wpływ nie tylko na teologię, lecz również na filozofię. Luter, interpretuje Heidegger, wpłynął przede wszystkim na filozofię niemieckiego idealizmu. „Fichte, Schelling i Hegel przychodzą z t e ologi i i czerpią z niej podstawowe bodźce dla swoich spekulacji. Ta teologia jest zakorzeniona $\mathrm{w}$ reformatorskim, [...] podstawowym nastawieniu Lutra. To podstawowe nastawienie ze swej strony dojrzało z jego źródłowej, poświęconej Pawłowi i Augustynowi wykładni, przy jednoczesnym zmaganiu i rozprawianiu się z późnoscholastyczną teologią (Duns Scotus, Okham, Gabriel Biel, Gregor z Rimini)"16.

Ostateczny przełom w kierunku Sein und Zeit dokonuje się w wykładzie Ontologie. Hermeneutik der Faktizität z 1923 roku. W tym tekście Heidegger wskazuje jeszcze raz na swoją drogę myślową, kiedy powiada: „Towarzyszem w poszukiwaniu był młody Luter, przykładem Arystoteles, którego tamten nienawidził. Bodźce dał Kierkegaard, a oczy włożył mi Husserl"17. Heidegger widzi w Lutrze teologa krytycznie odnoszącego się do przeformowania chrześcijańskiej teologii i kierującego sprzeciw wobec wyrażonego w niej doświadczenia greckiej filozofii. Luter wpłynął nie tylko na Heideggera rozumienie filozofii, lecz przede wszystkim na Heideggera rozumienie teologii, które miało się wyraźnie pokazać w wykładzie z 1917 roku zatytułowanym Phänomenologie und Theologie ${ }^{18}$.

\footnotetext{
${ }^{16}$ M. Heidegger, Phänomenologische Interpretationen zu Aristoteles, s. 369.

${ }^{17}$ M. Heidegger, Ontologie. Hermeneutik der Faktizität, Band 63, Gesamtausgabe, Hrsg. K. Bröcker-Oltmanns, Vittorio Klostermann, Frankfurt am Main 1995, s. 5.

${ }^{18}$ M. Heidegger, Phänomenologie und Theologie, [w:] tenże, Wegmarken, Band 9, Gesamtausgabe, Text mit Randbemerkungen des Autors aus den Handexemplaren, Hrsg. F.-W. von Herrmann, Vittorio Klostermann, Frankfurt am Main 2004.
} 
Istotne dla rozumienia przez Lutra teologii Pawła okazało się zmierzenie się z Augustynem. Heidegger zauważa: „Luter stał w swoich decydujących latach rozwoju pod silnym wpływem Augustyna. W obrębie protestantyzmu Augustyn jest najbardziej cenionym ojcem Kościoła" ${ }^{19}$. Luter wpłynął nie tylko na nowe rozumienie pierwotnego chrześcijaństwa. „Zdobycze poznawcze Lutra z jego wcześniejszego okresu są decydujące dla duchowego związku chrześcijaństwa i kultury. Jest to dzisiaj zapoznane, przy beztrosce o odnowę chrześcijańsko-religijną" ${ }^{20}$. Beztroska o odnowę chrześcijańsko-religijną odnosi się przede wszystkim do wczesnej filozofii religii Maxa Schelera i usiłowań protestanckiej teologii liberalnej. Heidegger widzi u Lutra i mistyków podobny, nowy sposób religijnego doświadczenia. „U Lutra - także u mistyków - pojawia się przełomowa, niespotykana, oryginalna forma religijności” ${ }^{21}$. Przy tym jest przekonany, że rozumienie wiary w protestantyzmie gruntownie różni się od rozumienia wiary katolicyzmu. Wiara katolicka, którą rozumie Heidegger jako „utrzymywać-za-prawdziwe” (für-wahr-Halten) ma całkiem inne ufundowanie, niż fiducia (zaufanie, pewność) reformatorów. W tych samych wykładach $\mathrm{z}$ lat 1920-1921 jest Luter wymieniony w powiązaniu z interpretacją Pawłowego listu do Galatów: „Luter i Paweł są religijnie najbardziej radykalnymi przeciwieństwami" 22 . Musimy jednak, chcąc komentować Pawła, uwolnić się od punktu widzenia i stanowiska Lutra, ponieważ „Luter widzi Pawła od strony Augustyna"23.

W 1920 roku został Heidegger powołany do Marburga, najstarszego na świecie uniwersytetu protestanckiego. Tam spotkał się z miejscową sławą, protestanckim teologiem biblijnym Rudolfem Bultmannem. Szybko nawiązała się między nimi współpraca, a potem przyjaźń. Heidegger powie później: „Bultmann i Jaspers są jedynymi, którzy mogą zrozumieć Sein und Zeit”. Heidegger i Bultmann spotykali się w sobotnie popołudnia, aby wspólnie czytać Ewangelię Jana. Tak powstał komentarz Bultmanna do Janowej Ewangelii. W spuściźnie Bultmanna znaleziono notatki z wykładu Heideggera o Arystolelesie i Kancie z semestru zimowego 1925/26. Heidegger zabierał głos na wykładzie Bultmanna w semestrze zimowym 1923/24 oraz latem 1927 na seminarium Bultmanna o wczesnym komentarzu Lutra do listu do Galatów. To tak zwane „wspólne seminarium” zostało uznane za „teologiczne

\footnotetext{
${ }^{19}$ M. Heidegger, Augustinus und der Neoplatonismus, Band 60, s. 159.

20 Tamże, s. 282.

${ }^{21}$ Tamże, s. 310.

${ }^{22}$ Tamże, s. 67.

${ }^{23}$ Tamże, s. 68.
} 
wydarzenie". W Zürichu w latach 1960/61 Heidegger uczestniczył w seminarium Gerharda Ebelinga, ucznia Bultmanna, dotyczącym interpretacji Lutra Disputatio de homine 1536.

Wiosną 1927 roku w 8. tomie Jahrbuch für Philosophie und phänomenologische Forschung ukazały się dwie prace, $\mathrm{z}$ którymi Edmund Husserl wiązał możliwości zastosowania jego filozoficzengo i fenomenologiczengo myślenia. W roczniku zostały opublikowane Heideggera Sein und Zeit i Oskara Beckera o sposobie istnienia tworów matematycznych pod tytułem $\mathrm{Ma}$ thematische Existenz. W tych burzliwych czasach, naznaczonych pierwszą wojną światową, jednostronnie zwrócono uwagę na Sein und Zeit. Jeżeli bycie (Sein) stało się przewodnim tematem Sein und Zeit, to znaczy, że Heidegger wyszedł nie tylko od scholastycznego arystotelizmu, lecz również od skotyzmu i mistyki mistrza Eckharta. Istotne jest to, że w Sein und Zeit nie są wymienieni autorzy ani teksty, które dla młodego Heideggera miały decydujące znaczenie. Nie pada nazwisko protestanckiego teologa Franza Overbecka, nie jest wymieniony Römerbrief ewangelicko-reformowanego teologa Karla Bartha. Być może „Zaciera Heidegger poprzez uczone wskazówki jak lis ogonem ślady własnej drogi?"”24 Kalwin i Zwingli są cytowani, kiedy analizuje powiązanie tradycyjnej definicji człowieka jako rozumnej istoty żywej $\mathrm{z}$ określeniem starotestamentalnym jako istoty stworzonej na obraz Boga ${ }^{25}$. We wprowadzeniu do Sein und Zeit zauważa Heidegger, że filozofia mogłaby owocnie zbudować relację do nauki, jeżeli krytycznie odniosłaby się do swoich podstaw. To samo dotyczy teologii tamtych czasów. Mówi Heidegger o teologii: „Rozpoczyna powoli znowu rozumieć przekonanie Lutra, że jej dogmatyczna systematyka spoczywa na 'fundamencie', który nie pochodzi z pierwotnego wierzącego pytania i którego pojęciowość nie tylko nie wystarcza dla teologicznej problematyki, lecz zakrywa ją i pochłania"26. Mimo to Sein und Zeit oddziela ściśle teologię od filozofii. Upadek (Verfallen) Dasein, o którym mówi fenomenologia Heideggera, nie może być ujęty jako "'upadek' (Fall) z czystszego i wyższego 'pierwotnego stanu' (Urstand)" 27 . Nie mamy ontycznego doświadczenia ani ontycznej możliwości interpretacji tej sytuacji. Możemy mówić tylko na podstawie fenomenologicznego doświad-

${ }^{24}$ O. Pöggeler, Heidegger in seiner Zeit, Wilhelm Fink Verlag, München 1999, s. 268.

${ }^{25}$ M. Heidegger, Sein und Zeit, Band 2, Gesamtausgabe, Unveränderter Text mit Randbemerkungen des Autors aus dem „Hüttenexemplar”, Hrsg. F.-W. von Herrmann, Vittorio Klostermann, Frankfurt am Main 1977, s. 66.

${ }^{26}$ Tamże, s. 13.

${ }^{27}$ Tamże, s. 233. 
czenia. „Dlatego interpretacja egzystencjalno-ontologiczna nie formuuje też żadnej wypowiedzi ontycznej o 'zepsuciu ludzkiej natury', nie dlatego, że brakuje potrzebnych dowodów, lecz ponieważ jej problematyka znajduje się p r zed wszelką wypowiedzią o zepsuciu i niezepsuciu. Zepsucie jest ontologicznym pojęciem ruchu. Ontycznie nie decyduje się o tym, czy człowiek 'utonął w grzechu' w status corruptionis, czy przechodzi do status integritatis, czy też znajduje się w stadium pośrednim, status gratiae"28. Fundamentalno-ontologiczna wypowiedź stoi przed ontycznymi wypowiedziami, to znaczy wypowiedziami poszczególnych nauk, do których należy też teologia. Ontologiczno-egzystencjalna wykładnia upadku uprzedza ontyczno-teologiczną interpretację upadku jako grzechu i, być może, mogłaby służyć „korekcyjnie” przy teologicznym wyjaśnieniu grzechu. Upadek (Verfallen) zatem nie jest filozoficznym odpowiednikiem teologicznego pojęcia grzechu pierworodnego (Erbsünde, ursprüngliche Sünde, Ursünde) ani w ogóle upadku w grzech (Sündefall). Samo pojęcie upadku może pochodzić formalnie z języka teologicznego, ale w interpretacji Heideggera nabiera całkiem innego (ontologiczno-egzystencjalnego) sensu, niż nadała mu teologia. Upadek w Sein und Zeit ma sens upadania Dasein w codzienność (Alltäglichkeit), w niewłaściwość (Uneigentlichkeit), w masową bezosobowość (das Man); jest ucieczką przed śmiercią (Flucht vor dem Tod). W Sein und Zeit wymienia Heidegger Lutra przy analizach fenomenów strachu (Angst) i lęku (Furcht), które występują w chrześcijańskiej teologii w powiązaniu z takimi fenomenami, jak wiara, grzech, miłość, żal ${ }^{29}$. U Lutra problem lęku pojawia się, w wykładni Heideggera, w związku z interpretacją poenitentia (pokuta, żal) i contritio (nawrócenie) w Genesiskommentar. Lutra wykładnia upadku w grzech jest powiązana, tak samo jak u Augustyna i Kierkegaarda, z wykładnią strachu i z chrześcijańskim spojrzeniem na śmierć.

\footnotetext{
${ }^{28}$ Tamże, s. 238.

${ }^{29}$ Tamże, s. 253.
} 


\section{Problem grzechu u Lutra}

Czternastego i dwudziestego pierwszego lutego 1924 roku w Marburgu, na seminarium z egzegezy biblijnej u Rudolfa Bultmanna, Heidegger wygłosił dwuczęściowy referat pod tytułem „Problem grzechu u Lutra”30.

$\mathrm{Na}$ początku referatu Heidegger zwrócił uwagę na to, że problem grzechu nie powinien być traktowany jako przedmiot rozważania religijnego, tylko teologicznego. Grzech nie jest fenomenem religijnym, lecz pojęciem teologicznym. Przedmiotem teologii jest Bóg, a jej tematem człowiek w sposobie bycia wobec Boga. Bycie człowieka jest jednocześnie byciem w świecie i dotyczy go problematyka związana ze światem.

Problem grzechu u Lutra wiąże się ściśle, interpretuje Heidegger, z pierwotnym stanem przed grzechem, pierwotną niewinnością, sprawiedliwością człowieka (iustitia originalis) ${ }^{31}$. Trzeba najpierw postawić pytanie o bycie człowieka w momencie, kiedy z ręki Boga został powołany do życia w świecie. Człowiek musi być widziany z jednej strony jako summum bonum stworzenia, z drugiej natomiast strony jako stworzenie, w którym występuje możliwość upadku i bycia w grzechu. Od sposobu rozważania grzechu pierworodnego i upadku w grzech zależy także pojęcie zbawienia. Na podstawie rozumienia iustitia originalis można odczytać sens i istotę danej teologii. Im bardziej ważność grzechu będzie zapoznana, tym bardziej będzie pomniejszane znaczenie zbawienia i przez to straci na znaczeniu konieczność wcielenia Bożego. Tak więc w wykładni Heideggera można znaleźć u Lutra podstawową tendencję: zdeprawowania, corruptio bycia człowieka nie można nigdy ująć wystarczająco radykalnie. W ten sposób wypowiada się Luter przeciw scholastyce, która mówi o corruptio zawsze w sposób osłabiony i złagodzony. Ta tendencja do widzenia w byciu ludzkim radykalnego zepsucia jest pokazana zarówno w wcześniejszych rozważaniach teologicznych Lutra, jak i późniejszych.

W Quaestio de viribus et voluntate hominis sine gratia disputata $\mathrm{z} 1516$ roku Luter widzi, w interpretacji Heideggera, grzech nie jako stan wywołany dokonaniem złego czynu. Luter kieruje nasze spojrzenie na pożądanie, affectus, to znaczy na sposób bycia człowieka wobec rzeczy, wypływający z przywiązania

\footnotetext{
${ }^{30}$ M. Heidegger, Das Problem der Sünde bei Luther, [w:] B. Jaspert (Hrsg.), Sachgemäße Exegese, Die Protokolle aus Rudolf Bultmanns Neutestamentlichen Seminaren 1921-1951, N.G. Elwert Verlag, Marburg 1996, s. 28-33.

${ }^{31}$ Tamże, s. 29.
} 
do nich ${ }^{32}$. Człowiek przywiązany do rzeczy jest pochłonięty szukaniem własnej sprawiedliwości, quaerere iustitiam suam. Jednocześnie rodzi się w nim zwątpienie przed Bogiem, desperatio spiritualis, które nie pochodzi z wielości popełnianych grzechów, tylko z pożądania grzechu, affectus horrens peccatum. Grzech posiada źródło w nastawieniu do świata. Wymaganiem wobec teologii jest tak interpretować bycie człowieka, że z tego bycia może on zbliżyć się do Boga. Nie można tego bycia przedstawić jako dobrego, tylko jako bycie przeniknięte grzechem, ponieważ tylko tak może się człowiek uczyć miłości do Boga. Świadomość grzechu budzi miłość do Boga miłosiernego. Człowiek jest rozumiany jako istota ujmująca swoje bycie w formie przetrwania w świecie pełnym przeciwności. Bóg w swoim miłosierdziu wstrząsnął człowieczym szukaniem usprawiedliwienia na własną rękę, quaerere suam iustitiam. Wstrząs prowadzi do świadomości: od świata nie mogę nic oczekiwać. Tak więc Luter w wykładni grzechu, wbrew scholastyce, kładzie zdecydowany akcent na pożądanie ciała affectus carnalis i zepsucie, corruptio ludzkiego bycia.

Podstawową tezą (17) w Lutra Disputatio contra scholasticam theologiam z 1517 roku, w wykładni Heideggera, jest: jeżeli człowiek chce być jako Bóg, wtedy może popaść w stan grzechu ${ }^{33}$. Człowiek zmierza do tego, aby stać się Bogiem. I to jest właśnie istotą grzechu. Człowiek stawia się na miejscu Boga, velle se esse deum et deum non esse deum (Teza 25). Możliwość urzeczywistnienia się ludzkiej egzystencji nie leży w niej samej. Człowiek skazany jest na łaskę łask, wobec której buntuje się jako grzesznik (Teza 30). Każde ludzkie działanie jest grzeszne, ponieważ człowiek jest od początku napiętnowany grzechem; grzech należy do natury ludzkiego bycia (Teza 37). Te wypowiedzi, w intepretacji Heideggera, dzielą Lutra tak dalece od Arystotelesa i greckiej ontologii, że powie: totus Aristoteles ad theologiam est tenebrae ad lucem, cały Arystoteles ma się tak do teologii, jak ciemności do światła. Podczas gdy scholastyka „ochrzciła” Arystotelesa i uczyniła jego filozofię swoją podstawą, Luter wyklucza jakąkolwiek możliwość porozumienia między Arystotelesem i myśleniem teologicznym.

W Disputatio Heidelbergae habita z 1518 roku Luter broni 40 tez, 28 teologicznych i 12 filozoficznych. Heidegger bierze pod rozwagę tezy: 19, 21, 22. Luter przedkłada, w interpretacji Heideggera, dwa teologiczne stanowiska

\footnotetext{
32 Tamże.

33 Tamże.
} 
i sposoby rozważania ${ }^{34}$. Theologia gloriae oparta jest na intelektualnym poznaniu Boga niewidzialnego poprzez widzialne stworzenie. Naprzeciw teologii chwały stoi theologia crucis (teologia krzyża). Teologia krzyża jest dla Lutra właściwą i jedyną teologią. (Teza 19) Non ille digne Theologus dicitur, qui invisibilia Dei per ea, quae facta sunt, intellecta conspicit, nie jest teologiem ten, który ujrzał niewidzialność Boga przez to, co stworzone. Przedmiot teologii nie może być pozyskany na drodze metafizycznego rozważania świata. (Teza 21) Theologus gloriae dicit malum bonum et bonum malum, Theologus crucis dicit id quod res est, teolog chwały estetycznie zachwyca się nadzwyczajnością świata zmysłowego. Teolog krzyża mówi o rzechach takich, jakimi one są. (Teza 22) Sapientia illa, quae invisibilia Dei ex operibus intellecta conspicit, omnino inflat, excaecat et indurat, wasza mądrość, która widzi niewidzialność Boga z dzieł, jest całkowicie rozdymana, zaślepiona i zatwardziała. Scholastyka w interpretacji Heideggera, w przeciwieństwie do Lutra teologii krzyża, usiłuje najpierw określić bycie człowieka i świata, następnie dopiero poznanie Chrystusa.

Później w wykładzie „Augustinus und Neoplatonismus” podjął Heidegger jeszcze raz przedstawiony $w$ Heidelberger Disputatio temat interpretacji przez Lutra fragmentu z listu do Rzymian 1, 19, który w Heideggera tłumaczeniu brzmi: „To, co niewidzialne w Bogu jest od czasów stworzenia przez myślenie widziane na podstawie jego dzieł" ${ }^{35}$. W tym wykładzie, który Luter wygłosił jeszcze jako augustianin, teologia krzyża przeciwstawiona jest teologii chwały, usiłującej wychwalać dzieło stworzenia, kierując myśl na Boga. W wykładni Heideggera fragment listu do Rzymian powraca ciągle na nowo w pismach patrystycznych, w których będzie ujmowany jako platońska droga wznoszenia się ze świata zmysłowego do tego, co ponadzmysłowe, i będzie ciągle przytaczany na potwierdzenie Pawłowego platonizmu. Tekst Pawła wywołał wiele nieporozumień. Heidegger jest przekonany: „Dopiero Luter zrozumiał go właściwie po raz pierwszy. Luter pokazał w swoich pierwszych dziełach nowe rozumienie pierwotnego chrześcijaństwa" ${ }^{36}$.

Na początku drugiej części referatu Heidegger podejmuje ponownie rdzeń Lutra teologii grzechu. Natura ludzka jest zepsuta. Samo bycie ludzkie jako takie jest przeniknięte grzechem. Grzech nie jest niczym innym, jak przeciwieństwem wiary. Przy czym wiarą jest: stać wobec Boga. Grzech nie jest za-

\footnotetext{
${ }^{34}$ Tamże, s. 30.

${ }^{35}$ M. Heidegger, Augustinus und Neoplatonismus, Band 60, s. 281.

36 Tamże.
} 
tem brakiem moralnej nieskazitelności, tylko właściwym stanem człowieka. Grzech u Lutra nie jest pojęciem moralnym, lecz egzystencjalnym, na co wskazuje już pokreślanie affectus. Człowiek jest w całości i całkowicie grzesznikiem. Grzech nie jest moralnym defektem. Nie wyraża się w człowieku poprzez jakąś moralną świadomość, nie w tym, że "człowiek zauważa, że popełnił coś niewłaściwego.” Oprócz tego podstawowego określenia grzechu kieruje Luter również uwagę na egzystencjalny ruch, wywołany przez grzech: jeden grzech rodzi drugi i wciąga człowieka coraz głębiej. Właściwym grzechem jednak jest niewiara, incredulitas, odwrócenie się od Boga, aversio Dei. Temu doświadczeniu niewiary towarzyszy strach, a w dalszej konsekwencji: fuga, odium, desperatio, impoenitentia, ucieczka, wrogość, rozpacz, brak pokuty.

Jeszcze wyraźniej, w wykładni Heideggera, daje się pokazać to, co zostało dotychczas na temat grzechu powiedziane w komentarzu Lutra In primum librum Mose ennarrationes - Ennarrationes in Genesis Cap. I-IV z 1544 roku $^{37}$. Wielkość grzechu możemy rozpoznać dopiero wtedy, kiedy odnosząc stan grzechu do Boga, widzimy Boga jako Boga. Doświadczeniu grzechu towarzyszy jednocześnie doświadczenie Boga. Tylko wtedy możemy zruzumieć aversio Dei, odwrócenie się od Boga. Adam i Ewa nie będą kuszeni do określonego pojedynczego grzechu, lecz będą podburzani do wystąpienia przeciw Bogu i przeciw słowu Boga. Ich grzech polega na tym, że posłuchali głosu, który nie jest głosem Boga, że uwierzyli słowu, które nie pochodzi od Boga. Wraz z popadnięciem w grzech pierworodny utracą źródłowe bycie wobec Boga. Po popełnieniu grzechu Bóg stał się dla człowieka kimś nie do zniesienia. Człowiek jest przerażony Bogiem, ponieważ wstrząsnął on jego właściwym byciem. Ucieka przed Bogiem, dowodząc przez to umysłowego zepsucia, intellectum depravatum. Człowiek ucieka, ponieważ nie rozpoznaje, że grzech oznacza prawdziwe rozstanie się z Bogiem, vera discessio a Deo. Właściwy sens grzechu jest taki: kto raz ucieka, ten ucieka tak, jakby ciągle życzył sobie coraz dalej oddalać się w nieskończność; grzesznik fugit in eternum. W ten sposób ciężar grzechu pociąga zawsze wraz z sobą dalszy grzech i wywołuje wieczną zagładę, sic peccatum pondere suo semper secum trahit aliud peccatum, et facit aeternam ruinam. Adam błądzi aż do tego stopnia, że w rozpaczy oskarża Stworzyciela i czyni go winnym za to, co się stało. Posuwa się do accusatio et culpam a se in Creatorum transfert. Ewa, chcąc się usprawiedliwić, kieruje zarzuty pod adresem Boga jako stworzyciela węża

${ }^{37}$ M. Heidegger, Das Problem der Sünde bei Luther, s. 31. 
i określa go przez to twórcą grzechu, auctor peccati. To jest najwyższym stopniem grzechu, hic ultimus gradis peccati est. Mimo wszystko położenie oddalającego się od Boga człowieka jest jeszcze jakąś relacją do Boga. Ta relacja do Boga pokazuje się w spojrzeniu człowieka wstecz, w tym sensie, że Bóg jako auctor peccati zostanie odrzucony. Człowiek powiada: „Bóg nie jest Bogiem”. To grzeszne położenie człowieka jest uznane przez Boga jako najwyższa łaska summa gratia. Bóg okazał się dla człowieka możliwością usprawiedliwienia i zbawienia. Istotne jest, że Bóg po upadku nadal pozostał dla człowieka partnerem rozmowy, nie zamilkł, mówi loquitur. Trzeba zauważyć, że bycie Boga jest cały czas ujęte jako słowo, verbum, a podstawowe odniesienie człowieka do Boga jako słuchanie, audire.

Z przeprowadzonych analiz na temat grzechu u Lutra wyprowadza Heidegger następujące spostrzeżenie ${ }^{38}$ : Lutra nauka o grzechu jako podstawowej zasadzie wiary jest zorientowana w kierunku przeciwnym niż nauka o grzechu teologii scholastycznej. To znaczy, wyrażając się teologicznie: „Wiarę można rozumieć tylko wtedy, jeżeli rozumie się grzech, a grzech można tylko wtedy rozumieć, kiedy ma się właściwe rozumienie bycia człowieka" ${ }^{39}$.

\section{Zakończenie}

Po piewszej wojnie fenomenolog Husserl został powołany do Fryburga. Dziwił się, jak wśród jego uczniów i przyjaciół żydzi, protestanci i katolicy zmieniają wyznania, chociaż sam $\mathrm{w}$ wieku 27 lat przeszedł $\mathrm{z}$ judaizmu na protestantyzm. W 1918 roku Heidegger pożegnał się z katolicyzmem w liście do przyjaciela, teologa Engelberta Krebsa z 9 stycznia: „Wglądy teoriopoznawcze, przechodząc na teorię poznania dziejowego, sprawiły, że system katolicyzmu stał się dla mnie problematyczny i nie do przyjęcia - ale nie chrześcijaństwo i metafizyka, one jednak w nowym sensie. [...] Wierzę, że mam wewnętrzne powołanie do filozofii, i że poprzez jego wypełnienie w badaniach i w nauczaniu wniosę zgodny z moją mocą wkład w odwieczne przeznaczenie człowieka - $i$ tylko $w$ to, i że $\mathrm{w}$ ten sposób usprawiedliwię przed

\footnotetext{
38 Tamże, s. 32.

39 Tamże, s. 33.
} 
Bogiem moje Dasein i działanie." ${ }^{40}$ Decydujący powód, dlaczego system katolicyzmu stał się dla niego nie do przyjęcia, leży w tym, że przez studium protestanckiej teologii i akcentowanie przez nią bezpośredniej relacji wierzącego do Boga, powrót do pierwotnego chrześcijaństwa nabrał dla niego decydującego znaczenia.

\section{Bibliografia}

\section{Dzieła Heideggera:}

Heidegger M., Unterwegs zur Sprache, Band 12. Gesamtausgabe, Hrsg. von Fr.-W. von Herrmann, Text der durchgesehenen Einzelausgabe mit Randbemerkungen des Autors aus seinem Handexemplar, Vittorio Klostermann, Frankfurt am Main 1985.

Heidegger M., Aus der Erfahrung des Denkens, Band 13, Gesamtausgabe, Hrsg. H. Heidegger, Durchgesehener Text der Einzelveröffentlichungen, aufgrund von Verbesserungen des Autors in den Handexemplaren gelegentlich geringfügig geändert, Vittorio Klostermann, Frankfurt am Main 2002.

Heidegger M., Reden und andere Zeugnisse eines Lebens, Band 16, Gesamtausgabe, Hrsg. von H. Heidegger, Vittorio Klostermann, Frankfurt am Main 2000.

Heidegger M., Phänomenologische Interpretationen ausgewählter Abhandlungen des Aristoteles zur Ontologie und Logik, Band 62, Gesamtausgabe, Hrsg. von G. Neu mann, Text des Typoskripts mit den handschriftlichen Zusätzen und Randbemerkungen des Autors aus seinem Exemplar, Vittorio Klostermann, Frankfurt am Main 2005.

Heidegger M., Phänomenologie des religiösen Lebens, Band 60, Gesamtausgabe, Hrsg. von M. Jung, T. Regehly, C. Strube, Vittorio Klostermann, Frankfurt am Main 2011.

Heidegger M., Ontologie (Hermeneutik der Faktizität), Band 63, Gesamtausgabe, Hrsg. von K. Bröcker-Oltmanns, Vittorio Klostermann, Frankfurt am Main 1995.

Heidegger M., Wegmarken, Band 9, Gesamtausgabe, Hrsg. von Fr.-W. von Herrmann, Text mit Randbemerkungen des Autors aus den Handexemplaren, Vittorio Klostermann, Frankfurt am Main 2004.

${ }^{40}$ Cytowane za H. Ott, Unterwegs zu einer Biografie, Frankfurt am Main-New York 1988, s. 106. 
Heidegger M., Sein und Zeit, Band 2, Gesamtausgabe, Hrsg. von Fr.-W. von Herrmann, Unveränderter Text mit Randbemerkungen des Autors aus dem „Hüttenexemplar", Vittorio Klostermann, Frankfurt am Main 1977.

\section{Opracowania:}

Heidegger M., Welte B., Briefe und Begegnungen, Klett - Cotta Verlag, Stuttgart 2003. Heidegger und die Anfänge seines Denkens, Hrsg. A. Denker, H.-H. Gander, H. Zaborowski, Verlag Karl Alber, Freiburg-München 2004.

Jaspert B. (Hrsg.), Sachgemässe Exegese, Die Protokolle aus Rudolf Bultmanns Neutestamentlichen Seminaren 1921-1951, N. G. Elwert Verlag, Marburg 1996.

Luther M., Vorlesung über den Römerbrief, Hrsg. J. Ficker, Leipzig 1908.

Ott K., Unterwegs zu einer Biografie, Frankfurt am Main-New York 1988.

Pappenfuss D., Pöggeler O. (Hrsg.), Zur philosophischen Aktivität, Bd. 2: Im Gespräch der Zeit, Frankfurt am Main 1990.

Pöggeler O., Heidegger in seiner Zeit, Wilhelm Fink Verlag, München 1999.

Schütte H.-W., Religion und Christentum in der Theologie Rudolf Ottos, Berlin 1969.

\section{Abstract \\ Heidegger, Luther and the Problem of Sin}

Heidegger's Christian origin had a decisive influence on his philosophical thinking, as he himself admits. For some time he was even considered as a Christian thinker. In Marburg, inspired by the biblical theologian R. Bultmann, he applies his philosophical interest to Protestantism. He participates in meetings and seminars on the problems of Protestant theology. A particular expression of his interest in Protestant theology is noted in the presentation of a lecture on The Problem of Sin in Luther during the Bible Exegesis Seminary at Bultmann's. Among others, he was also inspired by Protestant theology in his work Being and Time. His concept of sin described there is essentially different from Luther's concept. Probably under the influence of the Protestant understanding of faith and the experience of faith in the early Christianity, Heidegger turns away from Catholicism, what he expresses in a letter to his friend Engelbert Krebs, although he never officially leaves the church.

Key words: Heidegger, Bultmann, Luther, christianity, fall, sin 